Годищњак Филозофског̄ факулиеиейа у Новом Саду, Къиг̄a ХХХVIII (2013)

Annual Review of the Faculty of Philosophy, Novi Sad, Volume XXXVIII (2013)

Соња Веселиновић

Филозофски факултет Универзитета у Новом Саду
УДК: 821.111-1.09 Plat, S.

Оригинални научни рад

\title{
О РЕЦЕПЦИЈИ ПЕСНИШТВА СИЛВИЈЕ ПЛАТ У НАШЕМ КУЛТУРНОМ ПРОСТОРУ*
}

У раду се даје преглед рецепције дела, првенствено поезије, америчке песникиње Силвије Плат у српској књижевности и култури. Платова је код нас најпревођенија међу енглеским и америчким песникињама уопште, али је то специфичан случај и у другим културама, нпр. немачкој. Рецепција дела Силвије Плат, у том смислу, репрезентативна је и у односу на одсуство рецепције дела неких других ауторки, али и због чињенице да њену поезију читају и шири читалачки кругови, а не само стручна публика, као што је претежно случај са преведеном поезијом.

Кључне речи: Силвија Плат, рецепција, америчка поезија, превод

Педесет година од смрти америчке песникиње Силвије Плат (Plath, 19321963) није само пригодна, већ и неопходна прилика да се направи ретроспектива њеног присуства у нашој преводној књижевности. Самим тим што је Силвија Плат једина од савремених ауторки Енглеске и Америке чија је поезија објављивана у оквиру засебних издања на српско(хрватско) м језику у другој половини XX века и првој деценији XXI века, јасно је да песникиња код нас има изузетну рецепцију. Трагична смрт створила је око ње својеврсни ореол мита и донела јој славу каква се није могла ни замислити за њена живота. Управо биографија начинила ју је својеврсном поетском хероином, иконом феминизма, истакнутим стваралачким узором песникиња. И у немачкој књижевности - по многим аспектима блиској нашој - Платова је најпревођенија америчка песникиња. Објављивање две њене биографије и избора из дневника и преписке изазвало је лавину интересовања. Само до 1993. године у Немачкој је збирка Ariel имала десет издања, a роман The Bell Jar је други пут преведен 1997. С једне стране, песникињино самоубиство навело је читаоце да се враћају њеној поезији и преиспитуjу је у светлу такве одлуке, док се, с друге стране, у критичким написима Платова почела појављивати уз имена као што су Вирџинија Вулф, Харт Крејн, Ернест Хемингвеј, Георг Тракл, а нарочито Пол Целан (Divers 2002:

* sonjecka@gmail.com

Рад је настао у оквиру пројекта 178005 Министарства за науку Републике Србије, насловљеног „Аспекти идентитета и њихово обликовање у српској књижевности”. 
210-211). Ипак, ова биографска грађа допринела је и томе да се раздвоји мит од стварности и лично од песничког, тако да ће „богатство грађе доступне у немачким преводима омогућити Платовој да у земљама немачког говорног подручја достигне статус какав је имала у Енглеској и Америци од средине 1960-их" (Divers 2002: 212).

У нашој култури може се уочити сличан пут рецепције дела Силвије Плат. Имамо први талас у виду превода по неколико песама у часописима и антологијама, почев од шездесетих година, а након посмртног објављивања Аријела у Енглеској (Faber and Faber, 1965) углавном се преводе песме из те

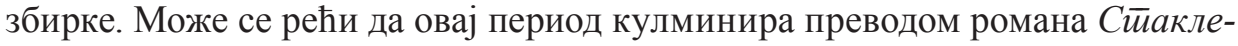
но звоно, објављеног 1976. године у издању угледне издавачке куће Нолит и преводу Бранка Вучићевића. Дакле, рецепцију је прво доживео аутобиографијом инспирисан роман Платове, објављен под псеудонимом Викторија Лука (Victoria Lucas) 1963, а не њена поезија. У наредном периоду, такође су објављивани бројни краћи избори у часописима као што су Кюижевна реч, Градина, Поља, Дело, Летиойис Майиие срииске, Мосӣови, с тим да у укупној рецепцији песникиње убедљиво предњачи Кюижевна реч. Библиографију превода и текстова о Платовој у периодици до 1998. сачинила је Даринка Влајковић у књизи песама Силвије Плат Рани одлазак. ${ }^{1}$ Колико је интересовање ова поезија изазвала показује и дуг списак преводилаца у датом периоду (М. Стефановић, Д. Трандафиловић, Ђ. Милановић, М. Пашић, В. Бајац, Ј. Ливада, М. Божин, Б. Јелушић, Н. Петровић, Н. Васовић, Љ. Ђурђић, И. Миланкова, С. Милетић и др.). Објављени су и документарни текстови попут писама и интервјуа са песникињом из периода непосредно пре смрти. Можда су, као и у Немачкој, управо ти текстови допринели све већем интересовању за Платову.

Десет година након објављивања прве њене књиге код нас, у загребачкој Просвјети објављене су Одабране ӥјесме у преводу Јадранке Слоковић-Глумац и са предговором Соње Башић, насловљеном „Поезија Силвије Плат”. У књизи су заступљене песме организоване по постхумним издањима: Колос (The Colossus and Other Poems): Колос, Црни гавран у кишном времену (Black Rook in Rainy Weather), Два погледа на собу са лешевима (Two Views of a Cadaver Room), Метафоре (Metaphors), Жабља јесен (Frog Autumn), Гљиве (Mushrooms), Зимски брод (A Winter Ship); Пријелаз иреко воде (Crossing the Water): Пријелаз преко воде, Пластична операција лица (Face Lift), Брање купина (Blackberrying), Окомита сам (I Am Vertical), У гипсу (In Plaster), Рани одлазак (Leaving Early), Догађај (Event), Ситне уре (Barren Woman), Огледало (Mirror), Живот (A Life), Размишљања (Apprehensions), Посљедње ријечи (Last Words); Зимска стиабла (Winter Trees): Зимска стабла, Дијете (Child), Жена без дјеце (Childless Woman), Други (The Other), Thalidomide, Сину без оца (For a Fatherless Son), Маријина пјесма (Mary’s Song), Јутарња

Уп. Силвија Плат, Рани одлазак, прев. Љиљана Ђурђић, БИГз-Чигоја штампа, Београд, 1998, стр. 223-227. 
пјесма (Morning Song), Гласници (The Couriers), Овца у магли (Sheep in Fog), Кандидат (The Applicant), Женски Лазар (Lady Lazarus), Тулипани (Tulips), Рез (Cut), Бријест (Elm), Ноћни плесови (The Night Dances), Макови у листопаду (Рoppies in October); Аријел: Аријел, Смрт \& Co (Death \& Co.), Ник и свијећњак (Nick and the Candlestick), Гуливер (Gulliver), Стизање (Getting There), Мјесец и тиса (The Moon and the Yew Tree), Рођендански поклон (A Birthday Present), Писмо у студеном (Letter in November), Супарник (The Rival), Грозница од 41 (Fever 103 ${ }^{\circ}$, Састанак пчела (The Bee Meeting), Долазак пчелиње кутије (The Arrival of the Bee Вox), Убоди (Stings), Презимљавање (Wintering), Мала фуга (Little Fugue), Године (Years), Минхенске кројачке лутке (The Munich Mannequins), Тотем (Totem), Паралитичар (Paralytic), Балони (Baloons), Макови у српњу (Poppies in July), Доброте (Kindness), Контузија (Contusion), Руб (Edge), Ријечи (Words). Преведене су готово све песме из Аријела. Превод Ј. Слоковић-Глумац углавном је прецизан, а у ситуацијама где је готово немогућно пратити основну семантичку нит, она се претежно одлучује за варијанту која подржава најшири спектар значења. Силвију Плат је захтевно преводити, са њеним често „леденим” тоном у којем има прегшт онога што би се на енглеском назвало understatement, уз потресну комбинацију патње, ироније и комичности (Divers 2002: 210). Иако препуна потресних тема, ова поезија је ипак усмерена ка адресату, тако да читалац често има сасвим одређену представу о тону песама Платове, али тешко оствариву на нашем језику.

У свом предговору, проучавалац америчке поезије Соња Башић види дело Платове у контексту кључног романтичарског преусмерења у историји светске поезије на „унутрашњи пејзаж свог бића”, на Ja у центру света. С друге стране, она сагледава Елиотов налог имперсоналности и отклон од њега у делима Р. Ловела, Џ. Беримена, Т. Реткеа, А. Гинзберга, Р. Крилија и С. Плат. Предочава тектонске промене у сувременој поезији:

Група тих пјесника као да стоји на размеђи модернизма и постмодернизма. Послије њих власт преузимају барбари: анархисти, визионари (махом ревизионистички), мађионичари, ситничари, еколози и зен-будисти, свакодневичари, сензибилисти, играчи игара. Спознаја да су хармонија, смисао, комуницирање, недостижне химере довела је модернисте до најцрњег песимизма, до бекетовског апсурда. Постмодернисти тврде да су прихватили апсурд, ништавило и немоћ језика, па зато пораз покушавају претворити у побједу. У литератури постмодернизма - неуредној, хазардерској, фантастичној - лирски или фикционални субјект често је гротескни кловн, алеаторички низ стања која више нису повезана у цјелину класиног „лика”, збир фонема у реченици, кемизам у недефинираном биолошком току, плод халуцинације. У Лоуелу, Бериману, Силвији Плат, то Ја припада, додуше, луђаку, болеснику, самоубојици (у дословном или метафоричком смислу) - али још увијек има неке велике атрибуте романтичарског лирског субјекта. То Ја је сад, међутим, солипсистички усмјерено на себе и у себе. (...) Конфесионални пјесник, осим тога, по дефиницији мора бити мрачан. (Plath 1986: 6) 
Соња Башић, дакле, не проблематизује дате исповедне позиције, већ их прихвата као аутентичне и противставља их постмодерном субјекту. Но, зар психички оболео субјект није управо школски пример непоузданог приповедача односно лирског $j a$ ? Ова поезија има своју врло карактеристичну реторику и позе, па и удвајања лирског гласа, а аутореференцијалност упорно доводи у питање спознају стварности и начине њеног представљања. Рекли бисмо да је „исповедна поезија” по многим својим поступцима постмодерна, али то пре свега зависи од начина на који јој приступамо. У време када су објављена кључна дела ових песника, појављује се, на пример, и Бледа вашира (Pale Fire, 1962) Владимира Набокова, која омогућава вишеструке паралеле.

У предговору се даље дају биографски подаци, кратка белешка Теда Хјуза уз хронологију песама из Аријела, као и сведене анализе неколико песама. Соња Башић истиче спорадичне мотиве и паралеле из историје, као и библијске и митске алузије. Она се надовезује на Хјузове речи о загонетној dramatis personae и о језику који је заправо директан, обичан говор, и показује како у њеној поезији „нема граница између оног тко говори, оног коме се говори и оног о коме/чему се говори. Сви се ти субјекти/објекти прелијевају, претачу, прелазе један у други, много чешће и радикалније него што то обично бива" (Plath 1986: 10). Из овога се види да почетно инсистирање на романтичарској традицији и исповедности није у складу са другим читалачким утисцима ауторке предговора, али када при крају текста помиње Едгара Алана Поа, може нам бити јасније на чији романтизам се мисли, односно на какво поимање субјекта. Јукстапозиција ирационалног и крајње рационалног, односно рационалан говор о ирационалном $а$ најбоље се може изучити на Поовим делима. Ауторка пише: „Упркос усијању њезина халуцинантног свијета, израз тог свијета у њезиним пјесмама необично је контролиран и одмјерен. Њезине су реченице синтактички и стилски строге и чисте, готово огољеле, а на најнеочекиванијим мјестима наилазимо на колоквијализме, каденце и тонове свакодневног дијалога. То, међутим, не значи да је Силвија Плат опуштени пјесник о 'обичним' стварима. Структура њезине пјесме увијек је чврсто саздана, направљена, 'зачудна"' (Plath 1986: 13-14).

Овај избор представљао је добар основ за наредну књигу поезије Платове, која се појавила две године касније, 1988. у Београду. Љиљана Ђурђић превела је збирку Аријел и написала поговор у овој књизи, насловљен „Силвија Плат \& Apијел”. Збирка обухвата песме: Јутарња песма, Весници, Овце у магли, Кандидат, Женски Лазар, Лале, Рез, Брест, Ноћне игре, Булке у октобрy, Berck-Plage, Аријел, Смрт \& комп., Лезбос (Lesbos), Ник и свећник, Гуливер, Стизање, Медуза (Medusa), Луна и тисово стабло, Рођендански дар, Маријина песма, Писмо у новембру, Супарник, Татица, Ти си (You're), Грозница $41^{\circ}$, Састанак пчела, Приспеће пчелињег сандука, Жаоке, Poj (The Swarm), Зимовање, Обешени (The Hanging Man), Мала фуга, Године, Минхенске лутке, Тотем, Паралитичар, Балони, Булке у јулу, Доброта, Модрица, Руб, Речи. У збирку су укључене и песме које су се појавиле само у америч- 
ком издању. С обзиром на култни статус ове књиге, објављивање ових песама на окупу подразумевало је и својеврстан манифест женске књижевности, одређивање наше средине према том изузетно ,заразном" и трауматичном рукопису који никога не оставља равнодушним.

Први део поговора Љиљане Ђурђић, „Силвија Плат и исповедна струја америчког песништва", у суштини се не бави толико овим односом, осим што прилично некритички приступа заправо негативној одредници „исповедна поезија". Не помиње се то да су Лоуелова поезија и поезија Платове блиске по одређеним темама, али да су њихове поетике и стваралачки поступци доста удаљени. С друге стране, уколико се већ говори о исповедном, могла би се истакнути Розенталова (M. L. Rosenthal) схватања бруталности и опште анксиозности након Другог светског рата, као реакције на неразумљиво зло и насиље. „Супротно херојском субјективном начину романтичара, исповедно $j a$ постављено је у центар песме тако да се говорникова психичка рањивост и самооптуживање хватају у мрежу ширих сила дезинтеграције у цивилизацији. Изневерени квалитет живота упија се натраг у сопство у замену за приватну и културну симболику" (Broe 1980: VII). У тексту Љ. Ђурђић опет се, изненађујуће, полази од Елиота и чак метафизичких песника, са њиховим conceits, мада је очигледно да необична сликовност и шокантне слике Платове могу имати ближи извор у надреализму и експресионизму. ${ }^{2}$ Очигледно је Елиот најпознатија референца из англо-америчке поезије од које је најлакше поћи. Текст Љиљане Ђурђић до краја је прилично конфузан када је реч о поетичким одређењима и теоријским поставкама. Иако се критички одређује према тумачењима ове поезије на основу биографије и психологије, она остаје у власти мита Силвије Плат и не пружа другачији приступ. Читав средишњи део поговора посвећен је биографији, а последњи, „О еротизму Силвије Плат”, креће се између Алварезових (Alvarez) идеја из књиге о самоубиству Окруйни бог (The Savage God: A Study of Suicide, 1972) и виђења еротизма Жоржа Батаја.

Историјски догађаји, политика, друштво, појављују се у поезији Силвије Плат одиста само маргинално, само као повод за изражавање и артикулисање еротске напетости, па су приче о њеном интензивном осећању кривице у односу на чињеницу концентрационих логора прилично исконструисане и натегнуте. (...) Област еротизма је област насиља, област силе, каже Батај, а други светски рат, као непосредна слика организованог насиља, нудио је педесетих и почетком шездесетих година још веома свежа сећања на дивљања слепе, убилачке силе, па се песничке асоцијације Силвије Плат већином везују за фашизам као најочи-

2 Подсетимо се да се у антологији British Poetry Since 1945 (1970) Едварда Луси-Смита, Силвија Плат заједно са Хјузом и Алварезом, налази у одељку „Ехpressionists”. У свом раду „Свет као икона: о темама Силвије Плат”, Анет Лејверс показује како функционишу боје и стални симболи у њеној поезији у вези са неким фундаменталним кодом, те да одређени елементи имају увек исту функцију, док неке боје могу бити и амбивалентне (црвена, плава). Уп. Annette Lavers, „The World as Icon: On Sylvia Plath's Themes", The Art of Sylvia Plath: A Symposium, ed. by Charles Newman, Indiana University Press, 1970, pp. 100-135. Врло слично они функционишу и у поезији експресионистичког песника опседнутог смрћу Георга Тракла (Trakl). 
тију инкарнацију зла и бивају подстицај за поетско-сексуалне екстазе у којима „Пепео Хирошиме помазује тела прељубника” а отац је „Не Бог него свастика”. (Плат 1988: 89-91)

Ауторка је понудила један начин да се приступи поезији Платове, али и када га представља, она се пре осврће на чињенице из живота него на оне литерарне. Нема увида у тумачења страних критичара који се не служе биографским методом, већ упућују на контекст, амерички и енглески (песници Покрета), европски, и тумаче песничке елементе и поступке. Проучаваоци попут Мери Лин Бро, на пример, предочавају да Платова никада није изгубила контролу над својом грађом, да њена поезија има много шири домет када јој се допусти да говори сама собом. Свакако да су овакви увиди много кориснији за рецепцију и репутацију Платове, него мистификације и митологизације. У својем раду „Аријел и друге песме”, Кристина Брицолакис скреће пажњу на то да се:

Експерименти Платове са гласом и персоном опиру тенденцији да се њена поезија чита као психобиографски наратив самооткривења. Оно што се понекад назива њеном 'исповедношћу', корисније је сагледати, показаћу то, као двојни дискурс, који, мада може бити заснован на аутобиографској грађи, онемогућава и песнику и читаоцу неку идентификацију са сигурношћу. За Платову, психичко је увек по себи позоришни простор, 'друга сцена', обложена многобројним текстовима и сликама. Упркос његовом привидном централном положају, дакле, место ја у овим текстовима јесте нестабилно и дволично, а ову нестабилност или двојност критичари често региструју као претњу, опасност или негативност и изједначавају је са самом женственошћу. С једне стране, она је запажена по својим животним и инвентивним метафорама; с друге, саме те метафоре обично поново призивају оптужбе за сценирање, реторичко прекорачивање или манипулативни сензационализам. Према неким читаоцима, она је крива за претеривање са метафорама, за неодговорно искоришћавање моћи аналогије, најозлоглашеније у позним песмама као што је „Татица”, које као у шали доводе историјске и психичке догађаје у изразито нестабилне метафоричке спојеве. Ови моменти метафоричких 'замисли“ смењују се са моментима лингвистичке регресије која ставља у први план материјалну основу значења: акустичке елементе језика као што су игре речи, ехо или нонсенс. (Britzolakis 2006: 108)

Управо ове димензије најчешће изостају у домаћим преводима. Два преводилачка приступа, Ј. Слоковић-Глумац и Љ. Ђурђић, и нису одвећ различита, што се нарочито може уочити у песмама експресионистички конципираним, са густим, херметичним сликама, будући да оне које су отвореније и комуникативније више зависе од тона но од сликовности.

У периоду од објављивања Аријела на српском језику, па до Раног одласка, следећег превода Платове, преводе њене поезије претежно је објављивала Љиљана Ђурђић. Занимљив прилог представљао је и превод „Писама Ричарду Марфију”, објављен у Лейойису Майице срӣске 1990. године уз текст самог Марфија, ирског песника, „Силвија Плат и Тед Хјуз. Излет у Западну Ирску, 1962. године”. Текст „Драмски портрет (замислио и по ауто- 
ровом рукопису адаптирао Бери Кајл)" штампан је у Писму 1992. Одломци из дневника објављени су у ProFemini, заједно са песмом Tpи жене, текстом „Силвија Плат суперстар” Ђурђићеве и изузетно значајним текстом о Платовој, „Два Аријела: поновно стварање канона Силвије Плат” Марџори Перлоф. ${ }^{3}$ Као и у Немачкој, управо се деведесетих година и код нас интересовање ширило преко биографских и документарних текстова. Књига Рани одлазак: изабране иесме појавила се 1998, у преводу Љ. Ђурђић. Као извор наводи се књига: Sylvia Plath, The Collected Poems (Harper \& Row). За разлику од прве преведене збирке, овде је начињен избор и песме су уређене хронолошки у распону 1956-1963.

Књига садржи песме: Две Персефонине сестре (Two Sisters of Persephone), Солилоквиј једног солипсисте (Soliloquy of the Solipsist), Госпођица Дрејк врши припреме за вечеру (Miss Drake Proceeds to Super), Уседелица (Spinster), Tyгованка (Maudlin), Одлука (Resolve), Сви наши мртви (All the Dead Dears), Музе неспокоја (The Disquieting Muses), Ноћна смена (Night Shift), Укротитељ змија (Snakecharmer), Трун у оку (The Eye-Mote), Два призора из мртвачнице, Метафоре, Електра у Алеји азалеја (Electra on Azalea Path), Пчеларева кћи (The Beekeeper's Daughter), Врт на имању (The Manor Garden), Тужне кртице (Blue Moles), Колос, Спаљивање вештице (Witch Burning), Камење (The Stones), Гљиве, Ти си, Обешени, Рани одлазак, Жена чувара зоолошког врта (Zoo-Keeper's Wife), Лифтинг лица, Јалова жена, У гипсу, Вертикална сам, Несаничар (Insomniac), Супарница, Брање купина, Последње речи, Огледало, Бебиситерке (The Babysitters), Три жене (Three Women), Привиђење (An Appearance), Прелаз преко воде, Ловац на зечеве (The Rabit Catcher), BerckPlage, Она друга, Речи које сам случајно чула преко телефона (Words heard, by accident, over the phone), Спаљивање писама (Burning the Letters), Рођендански дар, Састанак пчела, Приспеће пчелињег сандука, Жаоке, Рој, Зимовање, Муштерија (The Applicant), Татица, Медуза, Тамничар, Лезбос, Грозница 41 ${ }^{\circ}$, Посекотина, Аријел, Перда (Purdah), Женски Лазар, Стизање, Ноћне игре, Талидомид, Смрт \& Компанија, Зимска стабла, Бразилија (Brasilia), Минхенске лутке”, „Тотем”, „Паралитичар”, „Мистик”, „Руб”.

У предговору „Силвија Плат суперстар” сада су наглашени и неки други аспекти рецепције ове поезије, а поменута је и значајна литература на енглеском језику. Ауторка истиче посмртну популарност Платове, каква је честа у домену филмске и музичке индустрије, али не у књижевности, те анализира чиниоце који су довели до тог статуса поп-иконе и звезде. Ауторка се доста задржава на биографији, проучавајући околности одрастања

Ричард Марфи, „Силвија Плат и Тед Хјуз. Излет у Западну Ирску, 1962. године”, Лейойис Майице срйске, 445, 166, 4 (1990), стр. 616-622; Силвија Плат, „Писма Ричарду Марфију”, Исӣо, стр. 623627; Силвија Плат, „Драмски портрет: замислио и по ауторовом рукопису адаптирао Бери Кајл”, превеле Илеана Чура и Славица Поповић, Писмо, год. 8, бр. 31 (1992), стр. 203-230; „Три жене: песма са три гласа”, ProFemina, 1997, 11, стр. 137-146; „Дневници: одломци”, превела Жељка Јова-

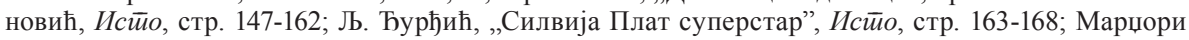
Перлоф, „Два Аријела: поновно стварање канона Силвије Плат”, Исйо, стр. 169-187. 
Платове, њене слабости и фиксације, а особито однос са ауторитативном мајком. Средишњи одељак, насловљен „Од чега је Силвија Плат правила своју поезију?", побраја теме и реалије на које се ослања њен песнички свет, а ауторка пише како се све песме лако тематски могу поделити на „песме које опонашају сексуални акт", песме о мајци, о супарницима, феминистичке, посвећене деци, болничке песме, песме о пчелама. Оваква тематска подела може деловати оперативно, али је врло наивна и превазиђена. Најзначајнији део предговора било би упућивање на специфичност њене метафоре и осећаја за језик, где се наводе и увиди Џона Фредерика Нимса (Nims):

Одбацујући сваку могућност настајања поезије као израза спонтаности, Нимс истовремено побија тврдње о Силвијиној поезији као производу манијакалне депресије и чак схизофреније, будући да је карактеришу изванредна контрола и велики рад: „Без кулучења са Колосом, тријумф Аријела би био незамислив.” Сама Силвија била је свесна овог: „Мислим да моје песме долазе право из мојих чулних и емотивних искустава, али морам да кажем да не могу да саосећам са оним вапајима из срца који нису изазвани ничим другим осим, знате, иглом или ножем, или нечим сличним. Верујем да човек треба да буде способан да контролише своја искуства и да управља њима, чак и оним најстрашнијим, као што је лудило, као што је мучење... И треба да управља тим искуствима једним обавештеним и интелигентним умом.” (Плат 1998: 15-16)

Штета је што више простора није посвећено овој проблематици, релевантној за посвећеније читање. Занимљиво је како овакве аутопоетичке изјаве саме песникиње нису чешће узимане као путоказ у тумачењу њене поезије. Предговор у књизи Рани одлазак завршава се кратком паралелом између Емили Дикинсон и Силвије Плат, питањем да ли је Платова била феминисткиња и цитатом из поговора Роберта Лоуела за америчко издање Аријела. Тиме овај предговор корисно отвара многе теме, не претендујући на пружање конкретних, једнозначних одговора. За контекстуализацију стваралаштва важна је и хронологија живота и рада, библиографија и литература на крају издања.

Веома је значајно што је Љиљана Ђурђић упорно радила на својим преводима, мењала неке детаље у складу са новим читањем и показала свест да превод може да застари, односно да одређено време и изражајне могућности циљне књижевности можда не умеју да понуде модусе транспоновања неких елемената оригиналног текста. Као и код других америчких песника, осетно је да су песме директног обраћања, конвенционалног речника, експлицитнијег израза, изгубиле нешто од свог тона и сугестивне, манипулативне моћи, но зато је превод убедљивији и успешнији кад је реч о остварењима комлекснијих слика и метафора, експресионистичке гротеске, оним семантички провокативнијим. И у засад последњој књизи поезије Платове на српском језику, проширеној верзији издања Рани одлазак (Paideia), која је објављена 2010. године, ${ }^{4}$ Љ. Ђурђић је уносила одређене измене у посто-

У наредном периоду и Сйаклено звоно је доживело друго издање 2001. и треће 2010, а оба је објавила издавачка кућа Paideia. 
јеће преводе и настојала да их реактуализује. Овде су заправо сабране песме из претходне две збирке, али су чак и многи наслови измењени у складу са новим читањем. Предговор је остао исти, али су белешке допуњене и збирка заиста представља корисно полазиште за сва даља проучавања и превођења Платове на српском језику.

Силвија Плат једна је од ретких преведених ауторки која се пробила у домаће песништво као узор, референца, цитат. Спектар песникиња и песника који су упућивали на њу и цитирали је врло је богат и не своди се на одређену генерацију, поетику, нити пол. У поезији најистакнутије савремене српске песникиње Радмиле Лазић (1949), која Платову види као један од својих узора - као, уосталом, и сама Љиљана Ђурђић - може се видети уплив оних реторичнијих, приступачнијих остварења, које се могу довести у везу са феминистичким приступом. Као и већина наших песникиња, нарочито млађих, Лазићева је склонија дискурзивнијем изразу, сличније Адријен Рич (Rich), али се Силвија Плат код многих наводи управо као икона, „суперстар”. Не може се рећи да на нашој сцени неко следи поетику Платове, авангардног исходишта и савремених тема суштински значајних за човека друге половине XX века, мада постоје услови за то, постоји традиција на коју би се надовезало, традиција Исидоре Секулић и Данице Марковић, као и авангардно наслеђе. Ипак, одређени језички поступци, групе метафора, сликовност на трагу њеног поетског израза присутни су спорадично у изразу домаћих аутоpa (А. Ристовић, Д. Вукићевић, Б. Стојановић Пантовић, А. Бешић, О. Недељковић и др). Силвија Плат је тема перформанса и монодрама, а појављује се и на интернет форумима који немају нужно везе са књижевношћу.

Богата рецепција изазвала је и пажњу научних посленика, што је кључно за подизање рецепције на виши ниво. Сунчица M. Getter одбранила је 2005. године магистарску тезу „Поетика Силвије Плат” на Филолошком факултету Универзитета у Београду. Азра Мушовић одбранила је на Филозофском факултету у Приштини магистарску тезу посвећену делу С. Плат 2009. године. Није чест случај да рецепција страних аутора не полази од уске, стручне рецепције, везане за факултет и презентовање канона одређене стране књижевности, већ од шире заинтересоване читалачке јавности. Сада се виђење Платове као јавне, егземпларне фигуре, према којој су се читаоци крајње опсесивно и посесивно опходили и наметали своје читање као једино исправно, помера на питања поетике и критичког проучавања естетског утиска који њено дело производи. Последњих година појављује се доста научних радова и есеја посвећених овој песникињи у часописима и зборницима, показујући опет да је спектар читалаца и проучавалаца Платове широк, мада међу њима преовлађују жене. ${ }^{5}$

\footnotetext{
Ивана Прентовић-Кривокапић, „Последњи месеци Силвије Плат”, Генеро, 8/9 (2006), 169-171; Сунчица Getter: „Лице у огледалу: мотив огледала у поезији Силвије Плат”, Лице у језику, књижевно-

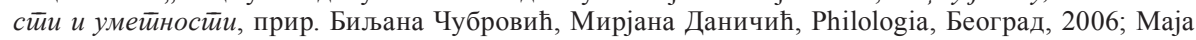
Солар, Драгослава Барзут, Тина Солар, „Мајке које нешто значе: о поетичким одликама стваралаштва Силвије Плат”, Сйање сйвари, 16 (2008), стр. 110-113; Азра Мушовић, „О креативности и
} 


\section{ЛИТЕРАТУРА}

Britzolakis, Christina (2006). „Ariel and other poems”. In: The Cambridge Companion to Sylvia Plath, ed. by Jo Gill. Cambridge University Press.

Broe, Mary Lynn (1980). Protean Poetic. The Poetry of Sylvia Plath. University of Missouri Press.

Divers, Gregory (2002). Image and Influence of America in German Poetry Since 1945. Camden House.

Plath, Sylvia (1986). Odabrane pjesme, prev. Jadranka Sloković-Glumac. Zagreb: Prosvjeta. Plath, Sylvia (2008). The Collected Poems. Harper Perennial Modern Classics.

Плат, Силвија (1976). Стаклено звоно, прев. Бранко Вучићевић. Београд: Нолит.

Плат, Силвија (1988). Аријел, прев. Љиљана Ђурђић. Београд: Народна књига.

Плат, Силвија (1998). Рани одлазак, прев. Љиљана Ђурђић, Београд: БИГЗ-Чигоја штампа.

Плат, Силвија (2010). Рани одлазак, прев. Љиљана Ђурђић, Београд: Paideia.

Плат, Силвија (2010). Стаклено звоно. Београд: Рaideia.

Sonja Veselinović

\section{THE RECEPTION OF SYLVIA PLATH'S POETRY IN SERBIAN CULTURE}

\section{SUMMARY}

This paper provides an overview of reception of Sylvia Plath's work, especially her poetry, in the Serbian culture and literature. Regarding our translated literature, Plath is the most translated author among all the American and English poetesses, but she holds a specific place in other cultures as well, such as German, for example. In this sense, the reception of Sylvia Plath's oeuvre is representative in relation to the lack of reception of some other authors, but also for the fact that her poetry is being read by the wider reading circles, not just the professional reading public (professors, critics, writers, translators), as is mostly the case with the translated poetry.

Key words: Sylvia Plath, reception, American poetry, translation

женском телу - уметничка визија Силвије Плат”, Зборник радова Филозофског̄ факулйейа, ур. Бранислав Милутиновић, Филозофски факултет у Приштини, бр. 40 (2010), стр. 129-138; „Бела богиња, Аријадна и мит о поетском ја: улога мита у формирању креативно-деструктивног односа Тед Хјуз - Силвија Плат”, Зборник радова Филозофског̄ факулӣеӣа, бр. 42/2 (2012), стр. 203-217; Snežana Simić, Autobiographical elements in the poetry of Sylvia Plath: master's degree thesis, Filološki fakultet, Beograd, 2011; Tijana Matović, Writing as an Act of Survival : Elements of Autobiography in Sylvia Plath's Poetry and Prose: Master Thesis, Filološko-umetnički fakultet, Kragujevac, 2012. 